\title{
Some Properties of the Galactanase Secreted by Phytophthora infestans (Mont.) De Bary
}

\author{
By M. KNEE* AND J. FRIEND \\ Department of Botany, The University, \\ Hull, HU6 7 RX
}

(Accepted for publication 27 September 1969)

\begin{abstract}
SUMMARY
Studies on the galactanase produced by Phytophthora infestans were facilitated by an improved culture medium for enzyme production. The enzyme degraded potato pectin until a proportion of the galactose units were released; short oligosaccharides probably occurred among the products of the reaction. The enzyme rapidly reduced the viscosity of potato and lupin pectin solutions, with a slower concomitant release of reducing groups. In addition it released total carbohydrate more rapidly than galactose from potato cell walls; these results indicate that the enzyme is an endo glycanohydrolase. It had a limited effect on the cohesion of discs of potato tuber tissue.
\end{abstract}

\section{INTRODUCTION}

Most fungal plant pathogens produce enzymes which degrade polygalacturonate and a smaller number produce enzymes which degrade cellulose (Wood, 1967); microbial polygalacturonate hydrolases and lyases and cellulases are quite well characterized (Bateman \& Millar, I966; Demain \& Phaff, I957; Wood, I960). On the other hand, glycosidases which degrade araban, galactan and xylan, which are often important components of plant cell walls, have been less widely found and less fully characterized. Arabanases have been reported from various microbial sources (Byrde \& Fielding, 1965; Fuchs, Jobsen \& Wouts, 1965; McClendon, Somers \& Heuberger, 1960) and the arabanase secreted by Phytophthora palmivora has been examined in some detail (Akinrefon, I968). Xylanases are known to be secreted by certain fungal plant pathogens (Hancock, I967; Sumere, Sumere-de Preter \& Ledingham, 1957). Galactanase activity has been attributed to Botryosphaeria ribis (McClendon et al. 1960) and to Sclerotinia sclerotiorum (Hancock, 1967), though never studied in any detail.

However, galactanase activity has been found in culture filtrates of Phytophthora infestans (Knee \& Friend, I968). The enzyme liberated galactose from potato pectin and from lupin pectin which contains a $\beta$-I,4 linked galactose polymer (Hirst, Jones $\&$ Walder, 1947) and it had negligible $\beta$-galactosidase activity. The object of this paper is to report more fully on this enzyme. Phytophthora infestans produces pectin methyl esterase (Clarke, I966; Grossmann, 1963) and though Grossmann (1963) reports the presence of endopolygalacturonase, this was not found by Clarke (1966) nor was any evidence of it encountered in the work described below.

* Present address: East Malling Research Station, East Malling, Maidstone, Kent. 


\section{METHODS}

In general the methods for culture of Phytophthora infestans, enzyme and substrate preparation, and enzyme assay were as described previously (Knee \& Friend, 1968). In the previous work low activities had been a hindrance and it was found that the addition of casein hydrolysate (Difco Ltd.) at the rate of $2 \mathrm{~g}$./1. to frozen bean medium resulted in greatly enhanced activity in the culture filtrates. Although a supplement of potato or lupin pectin gave a smaller enhancement it gave no advantage when added with casein hydrolysate. It was convenient to remove reducing sugars from the filtrates and further concentrate activity by ammonium sulphate precipitation, resuspension and dialysis; approximately $70 \%$ of total activity was recovered after these procedures. For routine assay of these more active preparations reducing sugar was estimated in duplicate $0.5 \mathrm{ml}$. samples taken at time intervals from a reaction mixture comprising $0.2 \mathrm{ml}$. enzyme, $2.0 \mathrm{ml}$. potato pectin solution $(5 \mathrm{mg} . / \mathrm{ml}$.), I.0 ml. citrate-phosphate buffer ( $\mathrm{pH}_{4} \cdot 0,0.062 M$ with respect to citrate) and I.8 ml. water.

\section{RESULTS}

\section{pH activity relationship}

Using the assay procedure of Knee \& Friend (1968), the activity of Phytophthora infestans galactanase was studied in relation to $\mathrm{pH}$ values between 2.5 and 7.0 (Fig. $\mathrm{r}$ ). Below $\mathrm{pH} 4.0$ the reaction slowed markedly with time so that while $\mathrm{pH} 3.5$ gave the optimal value at $30 \mathrm{~min}$, at 60 and $90 \mathrm{~min}$. the optimum shifted to between $\mathrm{pH} 4^{\circ} \mathrm{O}$ and 5.0 . When the $30 \mathrm{~min}$. reaction period was preceded by a $60 \mathrm{~min}$. incubation of the enzyme in buffer without substrate, the measured enzyme activity was reduced more at $\mathrm{pH} 3.5$ than at $\mathrm{pH} 4.5$.

\section{Extent of degradation of substrate}

Acid hydrolysis of potato pectin liberates galactose, estimated chromatographically (Wilson, 1959) as $3.2 \mu$ moles $/ \mathrm{mg}$. After $24 \mathrm{hr}$ digestion of potato pectin with galactanase the reducing sugar liberated was $2.4 \mu$ moles $/ \mathrm{mg}$., estimated in terms of galactose equivalents. However, paper chromatography (Fischer \& Dörfel, 1955) of this digest, followed by estimation of the galactose, indicated that $\mathrm{I} \cdot 5 \mu \mathrm{moles} / \mathrm{mg}$. were present. Other spots, which gave a weak reaction with aniline hydrogen phthalate reagent, were visible on this chromatogram; they did not correspond in position to arabinose or galacturonic acid (the other monosaccharide residues present in potato pectin) and may have been galactose-containing oligosaccharides.

It was thought possible that a more complete liberation of galactose might occur at low substrate concentrations. Thus initial activity and galactose produced in $24 \mathrm{hr}$ were estimated using a range of potato pectin concentrations, but the same enzyme concentration throughout.

From the results shown in Fig. 2 it can be seen that after a rapid liberation of reducing sugar, the extent of which increased with substrate concentration, a slower reaction set in so that after $24 \mathrm{hr}$ a constant proportion of the substrate was converted to reducing sugar. The reaction followed a similar course with lupin pectin as substrate. 
Viscosity change during action of galactanase

Potato and lupin pectin do not form highly viscous solutions. High concentrations (20 $\mathrm{mg} . / \mathrm{ml}$. digest) of the pectins were necessary to follow changes in viscosity during the action of galactanase. Viscosity measurements were based on the time taken for the meniscus of a solution at $20^{\circ}$ to pass between two graduations on a

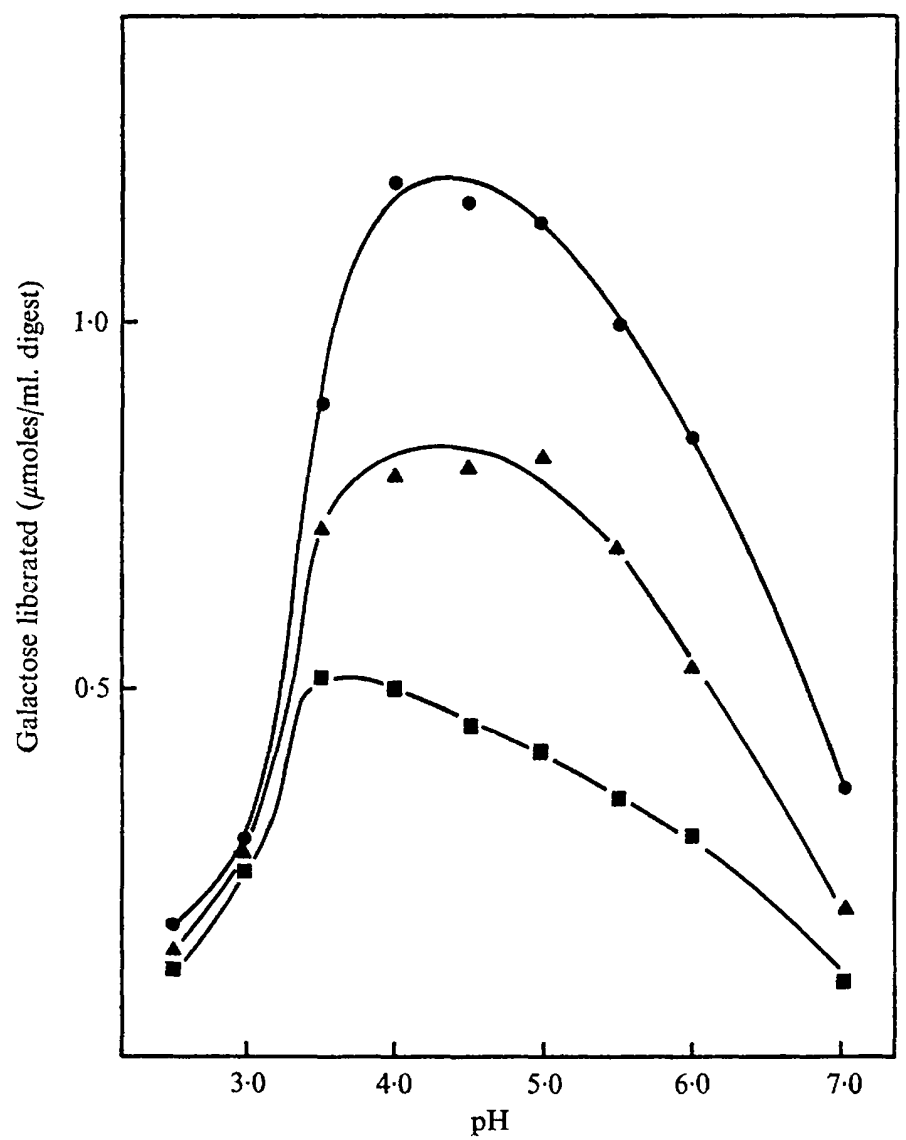

Fig. I. pH/activity relationship of Phytophthora infestans galactanase.

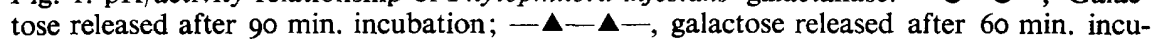
bation; - - - - galactose released after $30 \mathrm{~min}$. incubation.

vertically held pipette. As can be seen from Fig. 3, the enzyme rapidly reduced the viscosity of lupin pectin until about $2 \mathrm{hr}$ after the start of the experiment when a limiting value was approached. On the other hand reducing sugar was liberated at a more even rate over $4 \mathrm{hr}$, which was the duration of the experiment. From the experiments previously described it was to be expected that $48 \mu \mathrm{moles} / \mathrm{mg}$. reducing sugar would be formed if this reaction had gone to completion; at $2 \mathrm{hr}$, when viscosity had almost reached its lowest value, less than ro $\mu$ moles had been released.

The viscosity of a reaction mixture including boiled enzyme did not change throughout the course of the experiment and essentially similar results were obtained when potato pectin was used as a substrate. 


\section{Potato tuber cell walls as a substrate for galactanase}

Potato and lupin pectin are degradation products of polymers present in intact cell walls. In assessing the function of galactanase in the pathogenic interaction of Phytophthora infestans and potato tissue it is important to know how the native polymers would be attacked. Thus potato cell walls were prepared with the minimum of destructive pretreatment as follows.
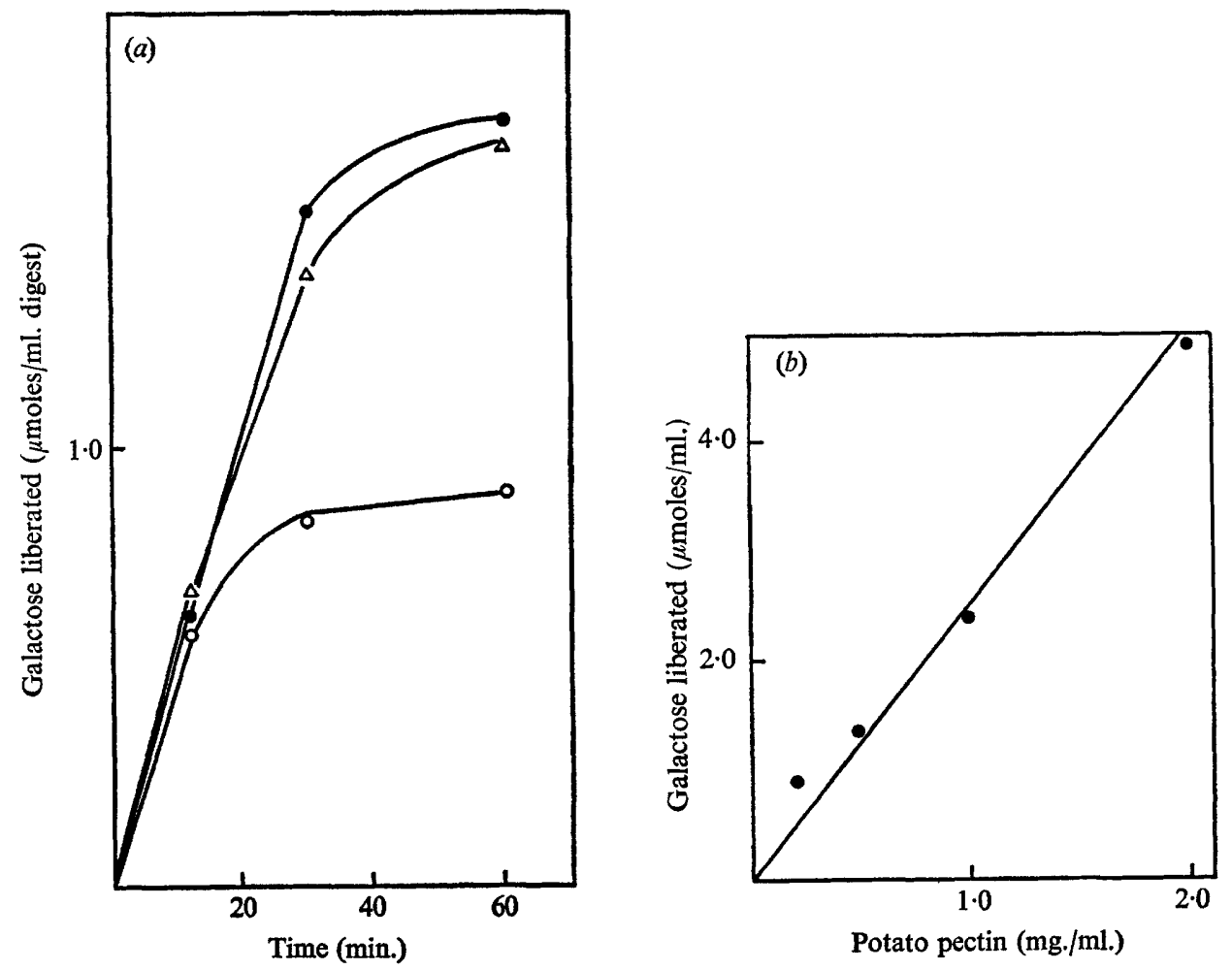

Fig. 2. Degradation of potato and lupin pectins by Phytophthora infestans galactanase.

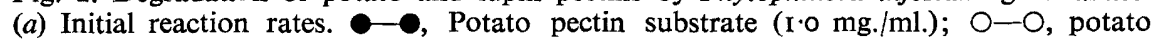
pectin substrate $(0.5 \mathrm{mg} . / \mathrm{ml}$ ); $\Delta-\triangle$, lupin pectin substrate $(1.0 \mathrm{mg} . / \mathrm{ml}$.). (b) Extent of degradation of potato pectin after $24 \mathrm{hr}$ incubation with the enzyme; the effect of substrate concentration.

Peeled King Edward potatoes were chopped and 100 g. disintegrated in a blender in $200 \mathrm{ml}$. of acetone, chilled to $-20^{\circ}$. The slurry was filtered through cheese cloth and the residue washed with a further $200 \mathrm{ml}$. chilled acetone, followed by $200 \mathrm{ml}$. chilled $70 \%$ ethanol and $1000 \mathrm{ml}$. iced water. The remaining 'paste' was frozen at $-20^{\circ}$ and ground to a powder in a chilled pestle and mortar; this powder was resuspended in $0.05 \mathrm{M}$-phosphate buffer ( $\mathrm{pH} 7.5$ ), filtered on muslin, washed with more buffer, followed by water and finally frozen at $-40^{\circ}$. This procedure gave a cell wall preparation relatively free from starch and cytoplasmic contamination, as seen under the microscope, and it did not darken in colour on being allowed to stand in air. 
A quantity of the frozen cell wall paste was suspended in deionized water to give approximately $\mathrm{I} 2 \mathrm{mg}$. cell wall $/ \mathrm{ml}$. suspension, equivalent to $5 \mathrm{mg}$. $/ \mathrm{ml}$. potato pectin.

Samples (2.0 ml.) of this wall suspension were transferred to flasks to which other additions were as for routine assay of the enzyme. Some of the flasks included fresh enzyme while in others the enzyme had been held at $100^{\circ}$ for $10 \mathrm{~min}$.; the flasks were incubated at $25^{\circ}$ with constant agitation for definite periods of time after which the contents were filtered on sintered glass (porosity 3 ) and carbohydrate in the filtrates estimated by three methods.

Negligible quantities of carbohydrate appeared in the filtrates from incubations

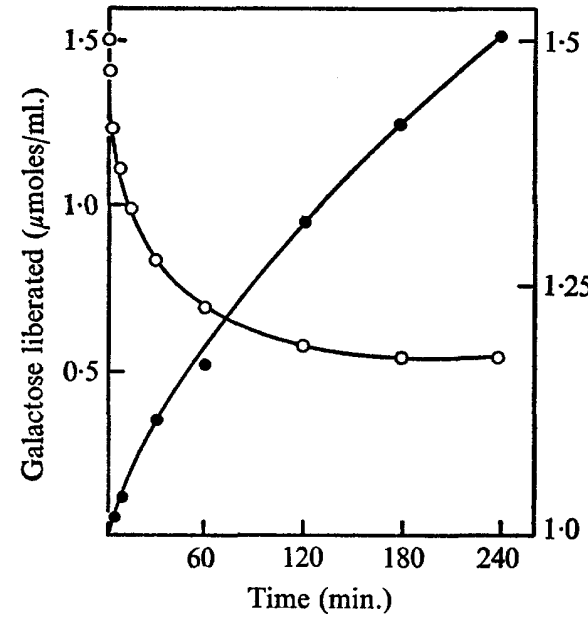

Fig. 3

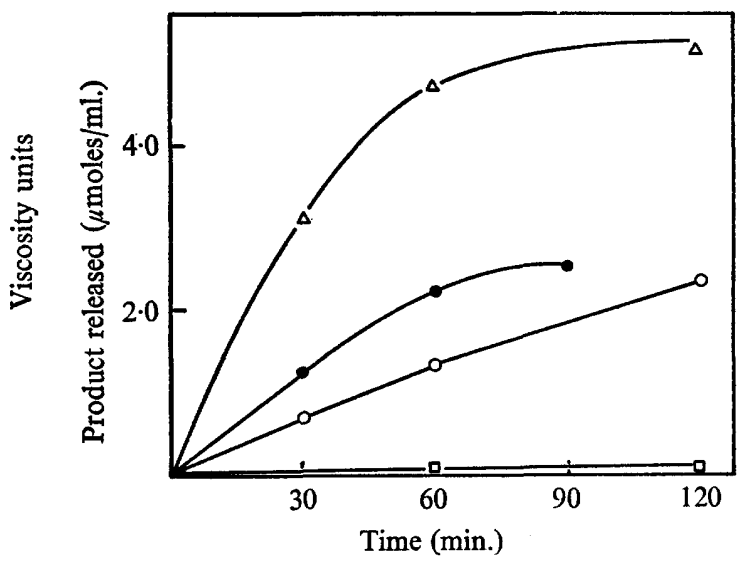

Fig. 4

Fig. 3. Viscosity change and reducing sugar liberated by action of Phytophthora infestans galactanase on lupin pectin. $\mathrm{O}-\mathrm{O}$, Change of viscosity relative to water; reducing sugar liberated.

Fig. 4. Action of a Phytophthora infestans galactanase preparation on potato tuber cell walls and on potato pectin. $\triangle-\Delta$, Total carbohydrate released from wall; $O-O$, reducing sugar released from wall; $\square-\square$, uronide released from wall; - , reducing sugar released from potato pectin.

with boiled enzyme. In filtrates from incubations with fresh enzyme total carbohydrate, estimated by the procedure of Devor (1950), increased rapidly to near a limiting value at two hours (Fig. 4). In these estimations, using randomly presulphonated $\alpha$-naphthol reagent, the absorption spectra of the products in the range $400 \mathrm{~nm}$. to $600 \mathrm{~nm}$. were typical of the sugar residues present (M. Knee \& J. Friend, unpublished results). In the filtrates from galactanase digests of the cell walls the relative absorbances at $480 \mathrm{~nm}$., $555 \mathrm{~nm}$. and $575 \mathrm{~nm}$. were almost exactly as predicted from a pure galactose sample.

Reducing sugar was liberated from the wall preparation at a little more than half the rate from a potato pectin substrate, and accounted for an increasing proportion of the total carbohydrate released (Fig. 4).

Uronide material in the filtrates was estimated by the procedure of McCready \& McComb (1952) and corrected for neutral sugar present. As can be seen from Fig. 4, very little was liberated in the course of the experiment. 


\section{Action of galactanase on potato tuber discs}

Discs of King Edward potato tuber ( $\mathrm{I} \cdot 0 \mathrm{~cm}$. diameter, $0.2 \mathrm{~mm}$. thick) were floated in batches of twenty on citrate-phosphate buffer $\left(\mathrm{pH}_{4} \cdot 0\right)$ in Petri dishes. A galactanase preparation was added to some of the dishes, to others was added a solution of commercial Pectinase (Sigma Chemicals Ltd.) of comparable glycosidase activity, and a control dish was included where water was added in place of enzyme.

The discs in various solutions were tested at various times for cohesion by attempting to draw them apart with mounted needles and by lifting them from the solution with a pair of forceps. Where galactanase was present the discs remained firm for several hours; $24 \mathrm{hr}$ after the start of the experiment there was a marked loss of cohesion, assessed with mounted needles, by comparison with control discs. At this stage the Pectinase-treated discs were completely lacking in cohesion.

\section{DISCUSSION}

In a previous paper (Knee \& Friend, 1968) it was reported that galactanase activity was detected in culture filtrates when Phytophthora infestans was grown on media containing lupin or potato pectin. It now appears that these supplements are not necessary for enzyme production; on the other hand the possibility that galactanase is an adaptive enzyme cannot be excluded as the basic culture medium may have included substances responsible for enzyme induction.

It was suggested previously that the simplest explanation of the data on the $\mathrm{pH} /$ activity relationship is that the enzyme is progressively inactivated at low $\mathrm{pH}$ values. Some experimental support for this suggestion was obtained by pre-incubating the enzyme with buffer at various low $\mathrm{pH}$ values for $\mathrm{I} \mathrm{hr}$ before addition of substrate. The pre-incubated samples showed less activity than untreated controls: $60 \%$ activity was retained at $\mathrm{pH} 3.5$ and $70 \%$ at $\mathrm{pH} 4.5$. If this explanation is correct then the results discussed below are subject to the proviso that activity has been studied at a $\mathrm{pH}$ value somewhat above the optimum for activity.

In the reaction of galactanase with potato pectin at $\mathrm{pH} 4.0$ a rapid liberation of reducing sugar occurred initially and continued for a period of time dependent upon the substrate concentration. Subsequently there was a much slower release of reducing groups until after $24 \mathrm{hr}$ a constant proportion of the original substrate had been degraded. Quantitative paper chromatography showed that free galactose comprised less than two thirds of the reducing sugar at $24 \mathrm{hr}$. The presence of probable oligosaccharides, which could not be estimated, on the chromatogram, may have accounted for the difference and A. L. J. Cole (personal communication) has confirmed the likely presence of the dimer, trimer and tetramer of galactose by another chromatographic method. It is characteristic of endoglycosidases that short oligosaccharides such as the dimer and trimer are not attacked or are attacked slowly (Phaff, I966; Schwimmer, 1950; Whelan \& Roberts, 1953), and the relative progress of the curves. for loss of viscosity and liberation of reducing sugar from potato and lupin pectin are suggestive of an endoglycosidase, as is the reaction of galactanase with a tuber cell wall preparation. The excess of total carbohydrate over reducing sugar liberated in the latter experiment probably reflects the polymeric state of the material released; once in solution this material would be further degraded by the enzyme. Thus two 
reactions probably occur, attack on the substrate in the wall leading to its dissolution and further degradation in solution.

Little or no uronide-containing material was liberated from the potato tuber cell wall preparation. This suggests that galactan in the walls is either independent of polyuronide or is attached to it only as side chains. Work on pectin composition has emphasised the importance of polyuronide as a structural component and the negative influence, if any, of galactan and araban side chains on the cohesive properties of this polymer (Gould, Rees, Richardson \& Steele, I965; Stoddart, Barrett \& Northcote, 1967).

However, galactan forms a large proportion of potato tuber cell walls (Friend \& Knee, 1969), and galactanase had a marked physical effect on a potato pectin substrate and a lesser effect on the cohesion of potato discs. Thus the enzyme might aid the penetration of tuber tissue during pathogenesis by Phytophthora infestans. Though activity was present in infected potato tuber discs degradation of galactan in this material was limited (Friend \& Knee, 1969).

The limitations of the work stem from various sources, particularly the fact that both enzyme and substrates must be regarded as impure. Galactan as such probably does not exist in nature (Barrett \& Northcote, 1965) though it is possible to prepare relatively pure galactose polymers, for instance from lupin pectin (Hirst et al. 1947). In view of the degraded nature of such a preparation it would be necessary to determine the average degree of polymerization of the polymer molecules, or preferably to derive fractions of uniform molecular weight by gel filtration, which could be tested separately as substrates. Analogous work has been carried out on $\alpha$-amylase from various sources (Bird \& Hopkins, 1954; Whelan, Bailey \& Roberts, 1953; Schwimmer, 1950; Whelan \& Roberts, 1953) and on an endopolygalacturonase (Phaff, I966).

We wish to acknowledge the constructive criticism by Professor N. F. Robertson of aspects of this work. Financial support was provided by the Agricultural Research Council, and part of this work was incorporated in a thesis (by M.K.) for the degree of Ph.D at the University of Hull.

\section{REFERENCES}

AkINREFon, O. A. (1968). Studies on the $\alpha$-L-arabinofuranosidase of Phytophthora palmivora (Butl.) Butl. New Phytologist 67, 543 .

Barret, A. J. \& NorthCOTE, D. H. (1965). Apple fruit pectic substances. Biochemical Journal 94, 617.

Bateman, D. F. \& Millar, R. L. (1966). Pectic enzymes in tissue degradation. Annual Review of Phytopathology 4, II9.

BIRD, R. \& HopkIns, R. H. (1954). The action of some $\alpha$-amylases on amylose. Biochemical Journal $56,86$.

BYRDE, R. J. W. \& FIELDING, A. H. (1965). An extracellular $\alpha$-L-arabinofuranosidase secreted by Sclerotinia fructigena. Nature, London $205,390$.

Clarke, D. D. (1966). Production of pectic enzymes by Phytophthora infestans. Nature, London 2Ir, 649.

Demain, A. L. \& PhafF, H. J. (1957). Recent advances in the enzymatic hydrolysis of pectic substances. Wallerstein Laboratories Communications 20, 119.

Devor, A. W. (1950). Carbohydrate tests using sulfonated $\alpha$-naphthol. Journal of the American Chemical Society 72, 2008.

Fischer, F. G. \& Dörfel, H. (1955). Die papierchromatographische Trennung und Bestimmung der Uronsäuren. Zeitschrift für physikalische Chemie 301, 224. 
FRIEND, J. \& KNEE, M. (1969). Cell wall changes in potato tuber tissue infected with Phytophthora infestans. Journal of Experimental Botany 20, 763.

Fuchs, A., Jobsen, J. A. \& Wouts, W. M. (1965). Arabanases in phytopathogenic fungi. Nature, London 206, 714.

Gould, S. E. B., Rees, D. A., Richardson, N. G. \& Strele, I. W. (1965). Pectic polysaccharides in the growth of plant cells: molecular structural factors and their role in the germination of White Mustard. Nature, London 208, 876.

Grossmann, F. (1963). Uber ein pektolytisches Enzym von Phytophthora infestans d. By. Naturwissenschaften 50, $72 \mathrm{I}$.

HANCOCK, J. G. (I967). Hemicellulose degradation in sunflower hypocotyls infected with Sclerotinia sclerotiorum. Phytopathology 57, 203.

HIRST, E. L., JoNES, J. K. W. \& WALDER, W. O. (I947). The pectic substances. Part VII. Constitution of galactan from Lupinus albus. Journal of the Chemical Society p. 1225.

KNEE, M. \& FRIEND, J. (1968). Extracellular 'galactanase' activity from Phytophthora infestans (Mont.) de Bary. Phytochemistry 7, 1289.

McClendon, J. H., Somers, G. F. \& Heuberger, J. W. (1960). The occurrence of a variety of enzymes hydrolysing cell wall polysaccharides in apples rotted by Botryosphaeria ribis. Phytopathology 50, 258.

MCCreAdy, R. M. \& MCCомB, E. A. (1952). Extraction and determination of total pectic materials in fruits. Analytical Chemistry 24, 1986.

PhafF, H. J. (1966). $\alpha$-I,4 polygalacturonide glycanhydrolase (endopolygalacturonase) from Saccharomyces fragilis. Methods in Enzymology 8, 636.

SCHWimmer, S. (1950). Kinetics of malt $\alpha$-amylase action. Journal of Biological Chemistry 186, I8I.

Stoddart; R. W., Barrett, A. J. \& NorthCote, D. H. (1967). Pectic polysaccharides of growing plant tissues. Biochemical Journal 102, 194.

Sumere, C. F. V., Sumere-de Preter, C. V. \& Ledingham, G. A. (1957). Cell-wall splitting enzymes of Puccinia graminis var. tritici. Canadian Journal of Microbiology 3, 76I.

Whelan, W. J., Batley, J. M. \& RoberTs, P. J. P. (I953). The mechanism of carbohydrase action. I. The preparation and properties of maltodextrin substrates. Journal of the Chemical Society $\mathrm{p}$. I293.

Whelan, W. J. \& Roberts, P. J. P. (1953). The mechanism of carbohydrase action. II. Amylolysis of linear substrates. Journal of the Chemical Society p. I298.

WILSON, C. M. (1959). Quantitative determinations of sugars on paper chromatograms. Analytical Chemistry 3I, I 199.

Wood, R. K. S. (1960). Pectic and cellulolytic enzymes in plant disease. Annual Review of Plant Physiology Ir, 299.

Wood, R. K. S. (1967). Physiological Plant Pathology. Oxford: Blackwell. 